\title{
Barriers to Student Learning and Participation in an Inclusive School as Perceived by Future Education Professionals
}

\author{
Pilar Arnaiz Sánchez ${ }^{1 *} \oplus$, Remedios de Haro Rodríguez² $\odot$, Rosa María Maldonado \\ Martínez $z^{3}$ • \\ 'Didactic and School Organization, University of Murcia, Spain \{parnaiz@um.es\} \\ 2Didactic and School Organization, University of Murcia, Spain \{rdeharor@um.es\} \\ 32Department of Education, Youth and Sports of the Region of Murcia, Spain \{rosamaria.maldonado@um.es\}
}

Received on 21 May 2018; revised on 23 May 2018; accepted on 25 June 2018; published on 15 January 2019

DOI: 10.7821/naer.2019.1.321

(c) BY-NC-ND

\begin{abstract}
Inclusive education represents the way forward to achieving high quality education systems, which are fair and equitable. This paper analyzes the barriers to learning and the current participation of schools in the promotion of inclusion from the perspective of future teaching professionals, specifically, 86 students from three Masters Courses in the Faculty of Education of the University of Murcia. A questionnaire was utilized in order to ascertain their perceptions of the limitations and obstacles present within the school context, the attitudes, the availability of resources and the adequacy of the educational response offered by the educational centres in which they had carried out their teacher training placements, with the aim of improving the future training of other students. A non-experimental narrative method was used. The results show many barriers and obstacles in the educational centres such as a lack of teacher training, which is needed to respond to the needs of all the students, the consideration that the diversity of the students is a problem, physical barriers, underuse of existing resources, as well as an educational response lacking in organizational and didactic strategies which does not take responsibility for a just and inclusive curriculum for all students.
\end{abstract}

KEYWORDS: INCLUSIVE EDUCATION, MASTER-DEGREE STUDENTS, TEACHER QUALIFICATIONS, RESOURCES IN SCHOOLS, INTEGRATED SCHOOLS.

\section{INTRODUCTION}

On the 70th anniversary of the Universal Declaration of Human Rights, promulgated by the UN in 1948, it made evident and reaffirmed once again that education is an inalienable right of everyone, which should underpin 21 st century education systems and societies deemed democratic. In this sense, and as prestigious and recognized authors and diverse institutions on the subject have indicated (Ainscow, Beresford, Harris, Hopkins, Southworth, \& West, 2016; Arnaiz, 2011; Escudero, 2006; UNESCO, 2017; Varcoe \& Boyle, 2014), we must con-

*To whom correspondence should be addressed:

Universidad de Murcia. Facultad de Educación. Departamento de Didáctica y Organización Escolar. Campus de Espinardo, 30.100. Murcia (España). tinue to strive to make the right to, inclusive equitable and quality education of all and for all a reality. As expressed by Torres (2017), our moral, intellectual and social obligation is to achieve a democratic education system in which equity, justice and equal rights prevail. Only in this way will it be possible to dismantle the architecture of existing inequality and exclusion and replace it with a just inclusive curriculum. In this sense, an education without exclusions is projected as an ecological model where the community, the family, the educational centres, the teachers and the students celebrate diversity and work in inclusive processes that aim for the maximum development of the person and their presence and participation in different areas of society (Mitchell, 2018).

For these reasons, policies on inclusive education, in their statements, actions and measures, should ensure that there is little difference between the declaration of intentions and educational practices (Arroyo \& Berzosa, 2018; Martín-Lagos, 2018). Ainscow \& Booth (2002) with regard to this, point out that educational cultures, policies and practices can favour or hinder the path towards inclusion, establishing barriers to learning and to the participation of students and the educational community and thereby generate exclusion and a lack of equity in education systems. These barriers must be identified and overcome so that a quality education of all and for all is possible. In this regard, Slee (2018) insists on the need to analyse the educational and social cultures and policies that favour inclusion in order to establish proposals for reform or change directed at supporting the needs of all students. Inclusive education requires immersion in a continuous research-action processes in centres of education which allow for the identification of their strengths, barriers and obstacles in order to establish improvement actions that favour fair and quality education for all (Chiner, Cardona \& Gómez, 2015; Escarbajal, Arnaiz, \& Giménez, 2017). For example, we point out how for students with specific educational needs support often suffers from the presence of these obstacles and barriers because they do not find themselves in democratically inclusive and fair schools.

The barriers to learning and participation have different natures and can occur at different levels such as the attitudinal, the organizational and the contextual. For this reason, it is essential that professionals in the field of education are aware of their existence, know how to identify them and are capable 
of proposing changes and improvements that eliminate them in order to offer inclusive responses to students. The importance given to this issue has been made by different authors (Colmenero \& Pegalajar, 2015; Luque, Gutiérrez, \& Carrión, 2018; Reoyo, Carbonero, Freitas, \& Valdivieso, 2012; Sánchez Palomino, 2009; Seville, Martín, \& Jenaro, 2017) inquire into the viewpoint and thoughts of future teaching professionals in education, in order to discover what the barriers to learning and participation that they encounter are in compulsory and post-compulsory education.

In the same way, it appears important to us that future professionals in the field of educational are aware of the existence of these barriers and do not perpetuate or develop them when they are in practice. Varcoe and Boyle (2014) complain about the work of universities in this regard. In the same way, López-Torrijo and Mengual-Andrés (2015), identify as a crucial aspect for the development of inclusion the formation of teachers and the development of competencies in students to be able to identify the strengths and weaknesses or barriers present in an educational institution in the interest of promoting inclusive educational practices.

In view of the above, the purpose of this work is to discover the viewpoint and thoughts of future professionals in the field of education, students on different masters courses in the Faculty of Education of the University of Murcia, concerning the barriers present in centres of education that hinder an inclusive education. In their undergraduate studies these students have carried out teacher training placements which have allowed them to visit educational centres in the region of Murcia and gain a specific viewpoint of the school context, the prevailing attitudes and the educational responses of the teachers when faced with students with specific educational needs support, as well as existing resources.

Therefore, in the study presented, we proposed as a general aim:

Analyse the barriers to learning and participation in developing inclusive education in educational centres from the of Master students' perception.

The specific objectives that stem from this aim are:

1. Identify the existing barriers in the school context and the attitudes of the teachers.

2. Identify the existing barriers regarding the availability of resources.

3. Detect the barriers present in the educational response.

4. Study the barriers according to the variables related to gender, age, Master's Degree entry requirements and master's degree course

\section{METHOD}

\subsection{Design}

It is a quantitative, non-experimental, narrative study. This will establish the main barriers to learning and participation, from the Masters students' perspective, and establish any possible significant differences encountered.

\subsection{Variables}

The predictor variables were: gender, age, master's degree entry requirements and master's degree course.

The criterion variables are represented by the 40 items present in the questionnaire, which in turn are grouped into three dimensions or variables which are: school context and predominant attitudes, availability of resources and educational response.

\subsection{Participants}

The participants in this study were students from three Masters Courses of the University of Murcia in the academic year 2016-2017: Master of Social and Educational Inclusion, Master of Research and Innovation in Nursery and Primary Education, and Master of Research, Evaluation and Quality. It is a non-probability sample, selected for convenience. The sample size with a confidence level of $95 \%(Z=1.96)$, and a sampling error of $5.3 \%$ rests with 86 participants. Table 1 shows the invited sample, the participant sample and the real sample of this study. In it, we can see the number of subjects of the population invited to participate $(\mathrm{N}=115)$, the subjects that agreed to be part of the study $(\mathrm{N}=88)$, and finally the sample that produces data $(\mathrm{N}=86)$.

Table 1. Number and percentages of the participants in the sample

\begin{tabular}{lcc}
\hline \multicolumn{1}{c}{ Type of sample } & N & \% \\
\hline Invited sample & 115 & $100,00 \%$ \\
Participant sample & 88 & $76,50 \%$ \\
Real sample & 86 & $74,70 \%$ \\
\hline
\end{tabular}

If we take into account the percentage of participants according tothesociodemographicorpredictorvariablesusedinthisresearch (gender, age, masters course studied and Master's Degree entry requirements), we can characterize the sample in more detail. Thus, 66 women and 20 men participated in this study. With reference to age, the largest number of participants is in the age range between 21 and 30 years old with a total of 76 subjects, in the age range of 31-40 years old we recorded 8 subjects, and only 2 Participants appear in the age bracket between 41 and 50 years old.

The Master's Degree entry requirements most represented with $51.2 \%$ of the sample or 44 subjects was the Degree in Primary Education and with $25.6 \%$ or 22 individuals, the Degree in nursery Education. The rest come from degrees in Specialist Foreign Languages Teaching: English and Teachers in Physical Education as well as the Degrees of Pedagogy and Psychology. Finally, the number of participants distributed according to the master's degree course is the following. $43 \%$ of the subjects belong to the course Master's degree in Social and Educational Inclusion-Exclusion: Politics, Programs and Practices; 40.7\% on the course Master's Degree in Research and Innovation in Nursery and Primary Education, and the remaining 16.3\% belong to the Master's Degree in Research, Evaluation and Quality in Education.

\subsection{Instrument}

The instrument selected for the collection of information was an ad hoc questionnaire. Its purpose was to understand the barriers to learning and participation, which exist in schools from the viewpoint of students on the master's degree courses, as well as a critical assessment of the commitment to the measures taken to promote inclusion.

Given its nature, the appropriate checks have been undertaken to provide a valid and reliable instrument (Cubo, Martín, \& Ramos, 2011). Therefore, once it was prepared, its validation was sought from several experts in the field, as well as 
the completion of a validation guide in order to ascertain their opinions and evaluations in relation to the issues raised. Some of the modifications and observations made by the experts and integrated into the final questionnaire, reference to the elimination of items, their grouping into dimensions and the letter of introduction were sent to the participants.

After the process of completing and entering the data and carrying out the necessary statistical analyses, Cronbach's alpha was $\alpha=.926$, which indicated a high reliability for the whole questionnaire. In the same way, this reliability is high, taking into account the three dimensions of the questionnaire, in School context and predominant attitudes $(\alpha=.850)$; in Availability and coordination of resources $(\alpha=.830)$; and in the Educational Response dimension $(\alpha=.859)$. In the instrument appear 40 items valued by a Likert type response scale which goes from 1 , strongly disagree, to 5 very much agree. The three dimensions present in the instrument, as we have expressed previously, are: a) School context and predominant attitudes (items 1-16), whose purpose is to ascertain the attitudes and expectations of teachers towards students with specific educational needs support and their level of training received to respond to the needs presented by this type of student. Likewise, also reflected is the feeling of belonging to the centre; the support and respect relationships within peers; the involvement and participation of the entire educational community; and the realization of awareness-raising activities of the educational community and ongoing teacher training aimed at inclusion. b) Availability of resources (items 17-24) where information related to the physical accessibility of the educational centres is collected, and the existence or not of resources and materials necessary to give an adequate response to the demands of students with specific educational needs support. c) Educational response (items 25-40) consisting of items that clearly reflect the type of educational response offered to students; whether the activities and methodology are adapted to the educational needs of the students; and the types of grouping of the students. Based on the data obtained in this dimension, it can be observed what the limitations in the educational response provided to the students are in order to offer an inclusive education.

\subsection{Procedure}

After reviewing various instruments and the literature related to the identification of the barriers to the development of inclusive education in the field of education (Ainscow, 2001; Ainscow \& Booth, 2002; Ainscow et al., 2016; Arnaiz \& Guirao, 2014, 2015; the Reine Guide prepared by the UDS State of Education, 2009), the instrument described above was constructed following the necessary steps in order to obtain its validity. Subsequently, we contacted the coordinators of the selected master's courses to inform them of the study to be carried out. With their approval, the different groups of students were approached through their representatives or group delegates, establishing the dates to inform the students about the purpose of the study and requesting their participation, collaboration and informed consent. The sessions lasted 40 minutes in each of the groups.

\subsection{Data analysis}

For the analysis of data the statistical program SPSS version 19.0 was used. With this software we proceeded to carry out a descriptive analysis (mean and standard deviations) for each of the dimensions as well as globally. In order to ascertain the possible significant differences present as a function of the predictor or socio-demographic variables of the sample, nonparametric statistics were used, due to the non-randomness of the sample since the data are measured on a ordinal scale, using the Kruskal-Wallis test for the comparison of means of more than two groups and the Mann Whitney U for two groups, adopting the level of significance of $p<0.05$

\section{RESULTS}

The results have been presented taking into account the specific objectives formulated in the study.

\subsection{Barriers Present in the school context and in attitudes}

The results presented in Table 2 show important obstacles within the school context of the centres in the promotion of an inclusive education from the viewpoint of the future teaching professionals. It is sufficient to take note of the low scores of items $1,2,4,7,10,11$ and 15 , which show the existence of important limitations in the school context and in the attitudes of many teachers from the perception of the participants in this study (master's degree students). In this way the barriers present in the school context refer to:

- The lack of positive attitudes among teachers regarding the incorporation of students with specific educational needs support $(\mathrm{M}=2.93, \mathrm{SD}=.089)$.

- The lack of positive expectations on the part of teachers regarding the abilities of all the students, teachers displayed weaknesses in their attitudes towards the diversity of the students and in particular of students with specific educational needs support $(\mathrm{M}=2.91, \mathrm{SD}=.990)$.

- Lack of teacher training to respond to the educational needs of all students, demonstrating the absence of competencies in teachers when facing the challenge of offering inclusive practices $(\mathrm{M}=2.38, \mathrm{SD}=.935)$.

- The absence of an adequate organizational structure to respond to the educational needs of all students, especially with reference to those most vulnerable $(\mathrm{M}=2.85, \mathrm{SD}=$ .0952).

- On the same theme, items 10 and 11 group barriers in relation to the non-development of activities for the ongoing training of teachers in matters of attention to diversity (M $=2.43, \mathrm{SD}=.094)$, as well as the lack of leadership from the management team in not energizing and promoting the implementation of training activities in this area $(\mathrm{M}=$ 2.72, $\mathrm{SD}=.095)$.

- Finally, we want to point out a series of items that, despite not obtaining very good marks, are closer to a level of agreement with the following statements, such as: in item 8 "The students understand and help their classmates who have specific educational needs support", we can see that the mean is close to $4(\mathrm{M}=3.60, \mathrm{SD}=.858)$. The same happens in item 3 , "Teachers present respectful attitudes towards all students, including those with specific educational needs support", we can say that the central trend is closer to $4(\mathrm{M}=3.91, \mathrm{SD}=.792)$.

The following table shows the issues described as well as the results obtained in each of the items referred to in this dimension. 
Table 2. Descriptive analysis for specific objective 1

\begin{tabular}{|c|c|c|c|}
\hline & $\mathbf{N}$ & Mean & $\begin{array}{l}\text { Standard } \\
\text { Deviation }\end{array}$ \\
\hline $\begin{array}{l}\text { 1. Teachers show positive attitudes } \\
\text { towards the incorporation of students } \\
\text { with specific educational needs } \\
\text { support. }\end{array}$ & 86 & 2.93 & .892 \\
\hline $\begin{array}{l}\text { 2. Teachers have high expectations of } \\
\text { every student's abilities. }\end{array}$ & 86 & 2.91 & .990 \\
\hline $\begin{array}{l}\text { 3. The teaching staff display a } \\
\text { respectful attitude towards all } \\
\text { students, including those who have } \\
\text { specific educational needs support. }\end{array}$ & 86 & 3.91 & .792 \\
\hline $\begin{array}{l}\text { 4. Teachers are trained to respond to } \\
\text { the educational needs of all students. }\end{array}$ & 86 & 2.38 & .935 \\
\hline $\begin{array}{l}\text { 5. Students with specific educational } \\
\text { needs support feel they belong to the } \\
\text { school as a member of a welcoming } \\
\text { community. }\end{array}$ & 86 & 3.20 & .992 \\
\hline $\begin{array}{l}\text { 6. The teaching staff tries to remove } \\
\text { the barriers that impede student } \\
\text { learning and participation. }\end{array}$ & 86 & 3.16 & .906 \\
\hline $\begin{array}{l}\text { 7. Educational tasks in the centres } \\
\text { are organized so that all students, } \\
\text { including the most vulnerable, learn. }\end{array}$ & 86 & 2.85 & .952 \\
\hline $\begin{array}{l}\text { 8. The student body understands } \\
\text { and helps peers who have specific } \\
\text { educational needs support. }\end{array}$ & 86 & 3.60 & .858 \\
\hline $\begin{array}{l}\text { 9. In the educational centre, the } \\
\text { diversity of the students is seen as a } \\
\text { value that enriches everyone. }\end{array}$ & 86 & 3.26 & 1.008 \\
\hline $\begin{array}{l}\text { 10. Activities are developed for the } \\
\text { on-going training of teachers with } \\
\text { regards to attention to diversity. }\end{array}$ & 86 & 2.43 & .940 \\
\hline $\begin{array}{l}\text { 11. The Management Team stimulates } \\
\text { and promotes the fulfilment of } \\
\text { activities for teacher training. }\end{array}$ & 86 & 2.72 & .954 \\
\hline $\begin{array}{l}\text { 12. Participation in the decision- } \\
\text { making of the entire educational } \\
\text { community is encouraged. }\end{array}$ & 86 & 3.03 & .939 \\
\hline $\begin{array}{l}\text { 13. Programs and activities are } \\
\text { developed to improve coexistence. }\end{array}$ & 86 & 3.16 & .866 \\
\hline $\begin{array}{l}\text { 14. Mutual support relationships are } \\
\text { fostered among the students. }\end{array}$ & 86 & 3.29 & .879 \\
\hline $\begin{array}{l}\text { 15. The centres promote campaigns of } \\
\text { awareness and sensitivity regarding } \\
\text { diversity. }\end{array}$ & 86 & 2.95 & 1.039 \\
\hline $\begin{array}{l}\text { 16. The involvement and participation } \\
\text { of families in their children's } \\
\text { education is encouraged. }\end{array}$ & 86 & 3.10 & 1.006 \\
\hline $\begin{array}{l}\text { SCHOOL_CONTEXT (global } \\
\text { variable for this dimension) }\end{array}$ & 86 & 30.560 & .51895 \\
\hline
\end{tabular}

\subsection{Existing barriers to the availability of resources.}

The mean of the responses to this dimension is below 3, showing their degree of disagreement with good resource planning to develop a quality and equitable education for all $(\mathrm{M}=2.77, \mathrm{SD}$ $=.661$ ). In Table 3, the barriers present in this dimension can be observed (items 17, 18, 20, 21 and 23), such as:

- For students with functional diversity the facilities and services of the educational centres are not easily accessible (M $=2.86, \mathrm{SD}=1.118$ ).
- In this same vein, the future teaching professionals consider that the centres do not have the resources and support to respond to students with specific educational needs support $(\mathrm{M}=2.67, \mathrm{SD}=.951)$.

- In the same way, they assert that information is not presented in different methods by which a student with a level of functional diversity can access it under conditions of equality $(\mathrm{M}=2.55, \mathrm{SD}=.893)$. Likewise, they perceive that information and communication technologies are not used as they should. $(\mathrm{M}=2.80, \mathrm{SD}=1.027)$, In these results it is explicit that these technologies are not used to facilitate or attend to the current needs of the students.

- Together with this, the measures taken to respond to the requirements of students with specific educational needs, support within the ordinary centres, are considered insufficient $(\mathrm{M}=2.21, \mathrm{SD}=.947)$.

- Finally, there is a lack of inclusive support measures within the ordinary classroom $(\mathrm{M}=2.64, \mathrm{SD}=.969)$, which shows evidence of a scarcity of resources and measures to offer attention to diversity both in quality and inclusiveness.

Table 3. Descriptive analysis for specific objective 2

\begin{tabular}{|c|c|c|c|}
\hline & $\mathbf{N}$ & Mean & $\begin{array}{l}\text { Standard } \\
\text { Deviation }\end{array}$ \\
\hline $\begin{array}{l}\text { 17. The facilities and services of the } \\
\text { educational centres are physically } \\
\text { accessible for students with } \\
\text { functional diversity (blind, deaf or } \\
\text { presenting with some difficulty). }\end{array}$ & 86 & 2.86 & 1.118 \\
\hline $\begin{array}{l}\text { 18. Schools have the resources and } \\
\text { support to respond to students with } \\
\text { specific educational needs support. }\end{array}$ & 86 & 2.67 & .951 \\
\hline $\begin{array}{l}\text { 19. The centre uses the resources } \\
\text { of the community for educational } \\
\text { purposes. }\end{array}$ & 86 & 3.33 & .900 \\
\hline $\begin{array}{l}\text { 20. ICT is used to respond to the } \\
\text { educational needs of students with } \\
\text { specific educational needs support. }\end{array}$ & 86 & 2.80 & 1.027 \\
\hline $\begin{array}{l}\text { 21. The information presented is } \\
\text { differentiated so that students with } \\
\text { any kind of functional diversity can } \\
\text { access it. }\end{array}$ & 86 & 2.55 & .893 \\
\hline $\begin{array}{l}\text { 22. Adapted materials are designed } \\
\text { or used for the students who need it. }\end{array}$ & 86 & 3.14 & .960 \\
\hline $\begin{array}{l}\text { 23. The measures to respond to } \\
\text { the needs of students with specific } \\
\text { educational needs support within } \\
\text { mainstream centres are sufficient. }\end{array}$ & 86 & 2.21 & .947 \\
\hline $\begin{array}{l}\text { 24. Inclusive support measures } \\
\text { are promoted (within the standard } \\
\text { classroom). }\end{array}$ & 86 & 2.64 & .969 \\
\hline $\begin{array}{l}\text { RESOURCES (global variable for } \\
\text { this dimension) }\end{array}$ & 86 & 27.774 & .66148 \\
\hline
\end{tabular}

\subsection{Barriers which exist in the educational response.}

The future teaching professionals have identified barriers in the educational response offered in the educational centres linked to aspects such as: the methodologies used, low motivation of students, the lack of an educational response adjusted to the needs of each student, the lack of differentiation in the proposed activities or lack of organizational and curricular strategies for attention to 
Table 4. Descriptive analysis for specific objective 3

\begin{tabular}{|c|c|c|c|}
\hline & $\mathbf{N}$ & Mean & $\begin{array}{l}\text { Standard } \\
\text { Deviatior }\end{array}$ \\
\hline $\begin{array}{l}\text { 25. Teachers promote the } \\
\text { participation and learning of } \\
\text { students with specific educational } \\
\text { needs support. }\end{array}$ & 86 & 3.08 & .910 \\
\hline $\begin{array}{l}\text { 26. Support for students with } \\
\text { specific educational needs } \\
\text { support is left to be carried out by } \\
\text { specialists. }\end{array}$ & 86 & 3.79 & 1.042 \\
\hline $\begin{array}{l}\text { 27. The methodologies used are } \\
\text { diverse. }\end{array}$ & 86 & 2.78 & .773 \\
\hline $\begin{array}{l}\text { 28. Students with specific } \\
\text { educational needs support are } \\
\text { motivated to be involved in their } \\
\text { own learning. }\end{array}$ & 86 & 2.92 & .961 \\
\hline $\begin{array}{l}\text { 29. Students with specific educa- } \\
\text { tional needs support receive an } \\
\text { individualized response to their } \\
\text { needs. }\end{array}$ & 86 & 2.99 & .976 \\
\hline $\begin{array}{l}\text { 30. The designed activities have } \\
\text { the necessary adaptations for } \\
\text { students with specific educational } \\
\text { needs support. }\end{array}$ & 86 & 2.87 & .865 \\
\hline $\begin{array}{l}\text { 31. The activities are planned } \\
\text { with different levels of difficulty } \\
\text { (multilevel teaching). }\end{array}$ & 86 & 2.66 & 1.013 \\
\hline $\begin{array}{l}\text { 32. An understanding of the } \\
\text { diversity of the students is } \\
\text { promoted within the programmed } \\
\text { activities. }\end{array}$ & 86 & 2.85 & .964 \\
\hline $\begin{array}{l}\text { 33. Tasks alternate between indi- } \\
\text { vidual work and group work. }\end{array}$ & 86 & 3.43 & 1.143 \\
\hline $\begin{array}{l}\text { 34. Learning contracts are esta- } \\
\text { blished with students. }\end{array}$ & 86 & 2.33 & .832 \\
\hline $\begin{array}{l}\text { 35. Cooperative learning strategi- } \\
\text { es are used. }\end{array}$ & 86 & 3.07 & 1.060 \\
\hline 36. Peer tutoring is developed. & 86 & 2.71 & 1.105 \\
\hline $\begin{array}{l}\text { 37. Groupings of students assist } \\
\text { the participation of students } \\
\text { with specific educational needs } \\
\text { support. }\end{array}$ & 86 & 3.31 & 1.055 \\
\hline 38. Flexible groupings are used. & 86 & 3.01 & 1.079 \\
\hline $\begin{array}{l}\text { 39. Methodologies are developed } \\
\text { based on the completion of Task } \\
\text { or Investigation Projects. }\end{array}$ & 86 & 2.34 & 1.080 \\
\hline $\begin{array}{l}\text { 40. The student corners } \\
\text { methodology is present in the } \\
\text { classroom. }\end{array}$ & 86 & 2.95 & 1.264 \\
\hline $\begin{array}{l}\text { EDUCATIONAL_RESPONSE } \\
\text { (global variable for this } \\
\text { dimension) }\end{array}$ & 86 & 29.433 & .57511 \\
\hline
\end{tabular}

diversity (learning contracts, peer tutoring, project-based learning, multilevel teaching), among other issues. All this is shown in Table 4, where we find values of the mean less than 3 for this dimension $(\mathrm{M}=2.94, \mathrm{SD}=.575)$, as well as for many of its items $(27,28,29,30,31,32,34,36,39$ and 40$)$ as:

- The lack of methodological diversity in teaching practices $(\mathrm{M}=2.78, \mathrm{SD}=.773)$.
- Lack of motivation for students to achieve their active involvement and participation in the learning process $(\mathrm{M}=2.92$, $\mathrm{SD}=.961)$.

- No offers of an individualized response to the students $(\mathrm{M}=$ 2.99, $\mathrm{SD}=.976$ ).

- The absence of the necessary adaptations in the learning activities for students with specific educational needs support $(\mathrm{M}=2.87, \mathrm{SD}=.865)$.

- The absence of multilevel teaching which is necessary to address diversity in inclusive contexts $(\mathrm{M}=2.66, \mathrm{SD}=1.013)$.

- An understanding of the diversity of the students is not promoted within the programmed activities, $(\mathrm{M}=2.85, \mathrm{SD}=.964)$.

- Similarly the future teaching professionals affirm that they did not encounter didactic and organizational strategies that promote inclusion such as: learning contracts $(\mathrm{M}=2.33, \mathrm{SD}$ $=.832)$, peer tutoring $(\mathrm{M}=2.71, \mathrm{SD}=1.105)$ project-based learning and research projects $(\mathrm{M}=2.34, \mathrm{SD}=1.08)$ and working in student corners $(\mathrm{M}=2.95, \mathrm{SD}=1.26)$.

- In the same way, they identify with a value close to agreement that the responsibility for students with specific educational needs support is left in the hands of specialists as shown in item $26(\mathrm{M}=3.79, \mathrm{SD}=1.04)$.

Therefore, after presenting the results obtained, it is possible to affirm the presence of barriers and important limitations in the educational response offered to students from the beliefs/viewpoint and perceptions of future teaching professionals, as shown in the following table.

\subsection{Barriers depending on the variables related to: gender, age, Master's Degree entry requirements and master's degree course.}

The intention of objective four is to discover if there are differences in the identification of barriers according to gender, age, master's course or entry requirements. And, where there are differences, disclose the groups affected. It should be noted that reference will only be made to the groups in which significant differences were found.

Once the necessary tests had been carried out, it was possible to verify that there are no statistically significant differences according to gender, age and degree. However, differences were observed in the barriers identified by the students on the different master course groups participating in this work, in two of the three dimensions that make up the questionnaire, the variable school context and predominant attitudes $(\mathrm{p}=0.02)$, in the educational response variable $(p=.004)$ and globally $(p=.002)$. Once the existence of differences is shown, it is necessary to look at which groups of masters produced this effect. Once all the possible combinations have been made, it can be confirmed that there are significant differences in two cases. On the one hand, between the Master's Degree in Social and Educational Inclusion-Exclusion: Policies, Programs and Practices and the Master's Degree in Research and Innovation in Nursery and Primary Education in the school context dimensions and predominant/prevailing attitudes $(\mathrm{p}=.002)$, educational response $(\mathrm{p}=.001)$ and globally $(\mathrm{p}$ $=.001)$. These differences are always favourable among students of the Master's Degree in Social and Educational Inclusion-Exclusion: Policies, Programs and Practices since they identify more barriers in the centres.

On the other hand, between the Master's Degree in Social and Educational Inclusion-Exclusion: Policies, Programs and Practices and the Master's Degree in Research, Evaluation and Quality in Education, differences are observed in the barriers identified by the students in one of the dimensions, school context $(\mathrm{p}=.008)$ 
and global level $(\mathrm{p}=.028)$, much more critical and identifying the largest number of barriers were students on the Master's Degree in Social and Educational Inclusion-Exclusion: Policies, Programs and Practices.

\section{DISCUSSION AND CONCLUSIONS}

The results shown above demonstrate the existence of barriers to learning and participation in educational centres in the promotion of inclusive educational practices if we take into account the opinions made by the master's degree students and future teaching professionals participating in the study. It is worth recalling, following Ainscow $(2001,2007)$, that one of the main tasks in developing an inclusive education is to identify the barriers that hinder the learning and participation of all students in order to eradicate inequality and establish educational equity. In this sense, Torres (2017) points out the need to carry out a school restructuring by the entire community from critical, transformative and participatory perspectives. This is evidenced by the results derived from this study. From their experiences the students of the three Master's courses in the Faculty of Education of the University of Murcia, as future professionals in the field of teaching, have identified weaknesses and limitations in the three dimensions of the developed questionnaire.

With regard to the first one, the context and predominant attitudes, two major barriers can be detected, both related to teacher training. The perception the master students have is that on the one hand the teaching staff of the centres are not prepared to respond to the needs presented by all the students and, on the other hand, the lack of projects developed at the core of the centre to promote change and improvement. In this sense, López Torrijo \& Mengual-Andrés (2015) point out the importance of teacher training for the success of inclusion. In the same way, Reoyo, Carbonero, Freitas \& Valdivieso (2012), in a study similar to ours, describe how the students perceive the importance of Secondary Education teacher training in the aspects curricular, emotional and relational. Also, different authors (Bisquerra, 2011, Escudero 2006, Krischesk \& Murillo, 2008), demand teacher collaboration and the need to share challenges and responsibilities in the centres for the democratic improvement of education. Combined with this, and as has been shown in other works (Arnaiz, De Haro, \& Guirao, 2015), it is possible to welcome and celebrate the multiple differences which exist in students, put in place positive expectations towards them, as well as have a distributed leadership promote campaigns of sensitization and awareness towards otherness, as Harris (2008) and González (2008) point out. Following Varcoe and Boyle, it is important to remember the importance of the teacher's attitude in the promotion of inclusion, recognizing and encouraging at the same time the role of universities in the development of such attitudes in teachers in-training.

With regards to the availability of resources, the second dimension analysed, the results obtained show the existence of important shortcomings in this area. From the perspective of future teaching professionals, the overall balance of this dimension reveals many barriers and limitations in the field of resources, preventing the students' enjoyment and benefit of equal opportunities. The lack of resources and their poor organization represent the materialization of important obstacles to learning and the participation of all students. It is necessary to highlight the importance of providing resources and support to offer a quality response to the demands presented by the students. In this sense, one of the barriers identified appears in relation to the use of ICT. As a matter of fact, the UNESCO Report (2008) indicates that teachers must be trained in ICT to empower their students. Likewise, Tejada and Pozos (2018) recognize ICT as a key factor for the transformation of educational practices, demanding initial and ongoing training of the teaching staff. Together with the above, one of the most striking pieces of data observed in this dimension is the lack of attention to diversity measures within the framework of ordinary education, as always, based on the viewpoint of the master students participating in this study. In this sense, we find on many occasions a whole series of measures described in the regulations but without practical application. Like Arroyo and Berzosa (2018) and Martín-Lagos (2018), we have identified the distance between ideals and practices, as well as between research and its transfer or application to educational centres. Starting from legislation, diversity is conceived as a challenge, many of the actions and measures designed by the educational administration continue to focus on difference from the deficit theory, perpetuating inequality and exclusion (Escarbajal, Arnaiz \& Giménez, 2017). These same ideas are expressed by Sevilla, Martín and Jenaro, (2017) in their study related to the perceptions of inclusive education of those students who are trained to be teachers in the state of Yucatán, pointing out the long way to go, not only in terms of the generation of knowledge but also in actions that allow teachers to change their perception.

Finally, with regard to the educational response, the analysed data shows important limitations, in relation to the methodologies used, to the limited adaptations of the activities designed to respond to the needs of the students and, above all, from the Masters students opinion, the assumption of the deficit model explained above, with the responsibility for students with specific educational needs support falling back on specialist. The latter is one of the most alarming data of all the results obtained since, as Bisquerra (2011), Colmenero and Pegalajar, (2015), responding to the needs of diversity should not be considered the exclusive task of specialist teachers, but has to be addressed by all teachers and from a framework of collaboration. The fact that attention to diversity rests solely with specialist teachers causes attitudes opposed to inclusion to be developed in schools. These attitudes are framed within a deficit model, in which the educational response focuses more on the difficulties than on the capacities of the students (Lledó \& Arnaiz, 2010).

Therefore, as confirmed by Arnaiz and Guirao (2014), schools are currently undergoing a process of transformation, which they must face in order to evolve according to the needs of society. Flexibility, creativity, tolerance and diversity are some of the characteristics that schools must have in order to adequately address all their students and develop an education for all. For this reason, they must opt for a model committed to inclusive education whose implementation is still a great challenge despite the numerous efforts that have been made in terms of inclusion, because there are still attitudes, practices and policies observed in the centres which hinder the development of an education for all.

The identification of the barriers present in the educational institutions by the students of the masters courses has shown significant differences in the comparison of the means with reference to the type of master's course. Concretely the students of the Master's Degree of Social and Educational Inclusion-Exclusion: Policies, Programs and Practices have been the most critical in identifying a greater number of barriers. As a matter of fact, it should be noted that the University of Murcia created this master's degree with the purpose of analysing social and educational inequalities, taking into account the values and principles characteristic of democratic, fair and equitable approaches on which quality and inclusive education should be based. It must prepare students by providing them 
with the necessary tools and techniques to investigate and analyse relationships at the macro, meso and micro levels, as well as identify situations in which there is a risk of exclusion and promoting the development of inclusive practices. The differences found may be due to this fact. Once again we are talking of the need for training in order to identify good practices.

In this way, the conclusions of the study show that the students of the master's courses have revealed, through their answers, the presence of barriers that limit the participation and learning of the students. They have identified barriers in the three dimensions that constitute the questionnaire, which in turn reveals the need to undertake changes and innovations at all levels of the current education system. Therefore, in the spheres of the school context and attitudes, it is necessary to rethink teacher training and encourage the proliferation of activities to raise awareness among teachers and the entire educational community.

Regarding the availability and coordination of resources, it is essential to highlight that it is very important to have the necessary resources to offer an adequate response, as well as the knowledge of how to use them, since the lack of these implies some elements of disadvantage and / or discrimination, since the non-use or non-availability of the necessary resources can be a great barrier, limiting the learning of the most vulnerable students. Likewise, the application of measures to address diversity within the standard framework is insufficient, which is a great obstacle for those students who demand certain resources and / or actions.

Finally, regarding the educational response, profound changes have to be undertaken, such as the use of varied methodologies adapted to the requirements of the students, the design of activities with different levels of difficulty so that everyone can learn and participate and, above all, being conscious that inclusion is the responsibility of all members of the educational community and society. These barriers are often present in the centres, as other studies have shown (Arnaiz, De Haro \& Guirao, 2015). In this sense, we must reduce the distance between research and educational policies, as indicated by Martín-Lagos (2018), by applying the necessary knowledge transfer. Undoubtedly, higher education centres have an important role to play in developing the necessary competencies in future teachers to promote an equitable and quality education for all, an inclusive education. One of these key competences will be to identify the barriers to learning and participation present in different educational contexts in order to eradicate them and establish change and improvement.

\section{REFERENCES}

Ainscow, M. (2001). Desarrollo de escuelas inclusivas. Ideas, propuestas y experiencias para mejorar las instituciones escolares. Madrid: Narcea. doi:10.1111/j.1471-3802.2007.00075.x

Ainscow, M. (2007). Taking an inclusive turn. Journal of Research in Special Educational Needs, 7(1), 3-7.

Ainscow, M., \& Booth, T. (2002). Guía para la evaluación y mejora de la educación inclusiva. Madrid: Consorcio Universitario para la Inclusión Educativa.

Ainscow, M., Beresford, J., Harris, A., Hopkins, D., Southworth, G., \& West, M. (2016). Creating the conditions for school improvement: A Handbook of staff development activities. London: Routledge.

Arnaiz, P. (2011). Luchando contra la exclusión: buenas prácticas y éxito escolar. Revista de Innovación educativa, 21, 23-35.

Arnaiz, P., De Haro, R., \& Guirao, J. M. (2015). La evaluación en educación primaria como punto de partida para el desarrollo de planes de mejora inclusivos en la Región de Murcia. Revista Electrónica Interuniversitaria de Formación del Profesorado, 18(1), 103-122. doi:10.6018/reifop.18.1.214351

Arnaiz, P., \& Guirao, J. M. (2014). Instrumentos para la autoevaluación y la mejora de la atención a la diversidad en centros educativos. Siglo Cero, 45(4), 22-47. doi:10.6018/reifop.18.1.214341

Arnaiz, P., \& Guirao, J. M. (2015). La autoevaluación de centros en España para la atención a la diversidad desde una perspectiva inclusiva: ACADI. Revista Electrónica Interuniversitaria de Formación del Profesorado, 18(1), 45-101.
Arroyo, M. J., \& Berzosa, I. (2018). Atención educativa al alumnado inmigrante; en busca del consenso. Revista de Educación, 379, 192-215.

Bisquerra, R. (2012). Diversidad y escuela inclusiva desde la educación emocio-nal. En J. Navarro (Ed.), Diversidad, calidad y equidad educativas (pp. 1-9). Murcia: Consejería de Educación, Formación y Empleo. Recuperado de http://sid. usal.es/idocs/F8/FDO26202/Diversidad_calidad_equidad.pdf

Chiner, E., Cardona, M. C., \& Gómez, J. M. (2015). Teacher's 'beliefs about diversity: an analysis from a personal and professional perspective. Journal of New Approaches in Educational Research, 4(1), 18-23. doi:10.7821/ naer.2015.1.113

Colmenero, M. J., \& Pegalajar, M. C. (2015). Cuestionario para futuros docentes de Educación Secundaria acerca de las percepciones sobre atención a la diversidad: Construcción y validación del instrumento. Estudios sobre Educación, 29, 165-189. doi:10.15581/004.29.165-189

Cubo, S., Martín, B., \& Ramos, J. L. (2011). Métodos de investigación y análisis de datos en ciencias sociales y de la salud. Madrid: Pirámide.

Escarbajal, A., Arnaiz, P., \& Giménez, A. (2017). Evaluación de las fortalezas y debilidades del proceso educativo en centros de infantil, primaria y secundaria desde una perspectiva inclusiva. Revista Complutense de Educación, 28(2), 427-433. doi:10.5209/rev_RCED.2017.v28.n2.49423

Escudero, J. M. (2006). Compartir propósitos y responsabilidades para una mejora democrática de la educación. Revista de Educación, 339, 19-41.

González, M. T. (2008). Diversidad e inclusión educativa: algunas reflexiones sobre el liderazgo en el centro escolar. Revista Electrónica Iberoamericana sobre Calidad, Eficacia y Cambio en Educación, 6(2), 82-99

Harris, A. (2008). Distributed leadership in schools: Developing the leaders of tomorrow. London: Routledge and Falmer Press.

Krischesky, G. J., \& Murillo, F. J. (2018). La colaboración docente como factor de aprendizaje y promotor de mejora. Un estudio de casos. Educación XXI, 21(1), 135-156.

López-Torrijo, M., \& Mengual-Andrés, S. (2015). An attack on inclusive education in Secondary Education. Limitations in initial teacher training in Spain. Journal of New Approaches in Educational Research, 4(1), 9-17. doi:10.7821/ naer.2015.1.100

Luque, A., Gutiérrez. R., \& Carrión, J. J. (2018). Análisis de las concepciones de los futuros profesionales de la educación de la Universidad de Almería sobre la atención al alumnado en audición y lenguaje. Profesorado. Revista de Currículum y Formación del Profesorado, 22(1), 133-157.

Lledó, A., \& Arnaiz, P. (2010). Evaluación de prácticas educativas del profesorado de los centros escolares. Indicadores de mejora desde la educación inclusiva. REICE, 8(5), 96-105.

Martín-Lagos, M. D. (2018). Educación y desigualdad: una metasíntesis tras el 50 aniversario del Informe Coleman. Revista de Educación, 380, 186-209.

Mitchell, D. (2018). The ecology of inclusive education strategies to tackle the crisis in educating diverse learners. London. Routledge. doi:10.4324/9781315110448

Reoyo, N., Carbonero, M. A., Freitas, A., \& Valdivieso, J. A. (2012). La percepción de los futuros profesores sobre los docentes de Educación Secundaria. International Journal of Developmental and Educational Psichology: INFAD. Revista de Psicología, 1(2), 389-396.

Sánchez, A. (2009). Integración educativa y social de los estudiantes con discapacidad en la Universidad de Almería. Almería: Universidad de Almería.

Sevilla, D. R., Martín, M. J., \& Jenaro, C. (2017). Percepciones sobre la educación inclusiva: la visión de quienes se forman para docentes. CPU-e. Revista de Investigación Educativa, 25, 83-113.

Slee, R. (2018). The inclusive education workbook. Teaching, learning and research in the irregular school. London: Routledge.

Tejada, J., \& Pozos, V. K. (2018). Nuevos escenarios y competencias digitales docentes: hacia la profesionalización docente con TIC. Profesorado. Revista de Currículum y Formación del Profesorado, 22(1), 25-51.

Torres, J. (2017). Políticas educativas y construcción de personalidades neoliberales y neocolonialistas. Madrid: Morata.

UNESCO. (2008). Estándares de competencia en TIC para docentes. París: UNES$\mathrm{CO}$.

UNESCO. (2017). Guía para asegurar la inclusión y la equidad en la educación. París: UNESCO.

Unidad de desarrollo Estatal de Educación (2009). Guia REINE. Reflexión Ética sobre la Inclusión en la Escuela. Madrid: FEAPS. Recuperado de http://sid. usal.es/idocs/F8/FDO19166/reine_inclusion.pdf

Varcoe, L., \& Boyle, C. (2014). Pre-service primary teachers' attitudes towards in inclusive education. Educational Psychology, 34(3), 323-337. doi:10.1080/0 1443410.2013 .785061

How to cite this article: Arnaiz Sánchez, P., de Haro Rodríguez, R., Maldonado Martínez, R. M. (2019). Barriers to Student Learning and Participation in an Inclusive School as Perceived by Future Education Professionals. Journal of New Approaches in Educational Research, 8(1),18-24. doi:10.7821/naer.2019.1.321 